\section{Islamic Legal hermeneutics on the Nafāqah during the Covid-19 Pandemic}

Journal of Islamic Legal Studies

$1(2)$ 47-67

(C)The Author(s) 2020

Reprints and permission:

Ulumuddin Prodi HKI FAI UMM

ejournal.umm.ac.id/index.php/ulum

\author{
Yulianti Muthmainnah \\ Ahmad Dahlan Institute of Technology and Business (ITB-AD), Jakarta, Indonesia \\ ymuthmainnah@gmail.com

\section{Revoluna Zyde Khaidir} \\ Al-Ishlah Islamic High College on Understanding the Qur'an and Sciences (STIQSI), \\ Lamongan, Indonesia \\ lunasendang@gmail.com
}

\begin{abstract}
Those who work and earn money in the public sphere are obliged to find alimony and provide a living (nafāqah). The assumption that has been believed by the Muslim society is that alimony is a man's duty (husband to wife, father to family). This assumption has been influenced by several factors such as language construction, state policies and the normative religious understanding. During the Covid-19 pandemic, this one-sided assumption has not only continued discriminatory for women and kept them away from such fair and equal economic access, but also it has tended to take Muslim families' economy into the risks. This article aims to examine the complexities of working women position in the Islamic legal jurisprudence and provide an alternative narrative of Islamic legal hermeneutics ensuring that the livelihoods do not become the domain of men alone. Accordingly, it can be argued that the alimony might be considered to become the obligation of both men and women equally. Interviews with a number of women at the grassroots level prove that women are being able to play roles in earning a living.
\end{abstract}




\begin{abstract}
Abstrak
Siapa saja yang bekerja dan menghasilkan uang di ruang publik, memiliki kewajiban untuk memberikan tunjangan dan nafkah (nafāqah). Asumsi yang berkembang dan diyakini oleh masyarakat Muslim adalah bahwa tunjangan dan nafkah tersebut merupakan kewajiban dari seorang laki-laki (suami kepada isterinya, ayah terhadap keluarganya). Asumsi ini berkembang karena dipengaruhi oleh beberapa faktor seperti misalnya konstruksi bahasa, kebijakan negara dan pemahaman keagamaan yang normatif. Selama merebaknya wabah pandemik Covid-19, asumsi bermata tunggal ini tidak hanya melanggengkan diskriminasi bagi para perempuan, namun juga menjauhkan mereka dari akses ekonomi yang setara dan adil. Tentu saja hal itu dapat membawa perekonomian keluarga-keluarga Muslim dalam resiko dan kerentanan. Artikel ini bertujuan untuk menganalisis kompleksitas posisi para perempuan pekerja menurut sudut pandang yurisprudensi hukum Islam dan memberikan narasi alternatif mengenai penafsiran hukum Islam dalam rangka memastikan bahwa mata pencaharian sebenarnya tidak menjadi domain laki-laki semata-mata. Karena itu, artikel ini mengajukan argumentasi bahwa tunjangan kehidupan dan nafkah sebenarnya dapat dipertimbangkan sebagai hal yang menjadi tanggungjawab bukan hanya laki-laki, namun juga perempuan secara setara. Berbagai wawancara yang dilakukan terhadap beberapa perempuan di akar rumput membuktikan bahwa para perempuan mampu memainkan peran penting dalam mencari nafkah.
\end{abstract}

Keywords: Nafāqah; alimony and provide a living; earning a living; gender equality; Islamic legal jurisprudence; Islamic legal hermeneutics; Covid-19 pandemic. 


\section{Introduction}

The outbreak of Covid-19 since the end of 2019 has triggered pandemic conditions throughout the world, including Indonesia. Reports say that men are more affected by the virus; virus-related death is experienced more by men than women. ${ }^{1}$ However, this narrow statement is not sufficient to illustrate the harsh reality faced by both men and women. ${ }^{2}$ In Policy Brief: The Impact of COVID-19 on Women, it is reported that many women get little to no salaries for their work. The same report also states that women's workload is not limited to work place, but also at home, since social order requires women to serve all family members who stay at home during the pandemic. ${ }^{3}$ In Indonesia, with the stagnation of the hotel business, fast food, hajj/ umrah business, travel services and entertainment venues, ${ }^{4}$ thousands of employees were forced to leave without severance pay or holiday allowances. ${ }^{5}$ Among those dismissed, 30 percent were female workers. Of the 32,000 migrant workers who were returned to Indonesia, 83 percent are women workers. ${ }^{6}$ This proves that the Indonesian women's workforce is huge, followed by signs that even in normal times, the need for women to work is great. During a pandemic, layoffs trigger

${ }^{1}$ Hua Cai, "Sex difference and smoking predisposition in patients with COVID-19," The Lancet, Respiratory Medicine 8, no.4 (April 2020): e20, https://doi.org/10.1016/S22132600(20)30117-X.

2 Jewel Gausman and Ana Langer, "Sex and Gender Disparities in the COVID-19 Pandemic," Journal of Woman's Health 29, no. 4 (April 2020): 465, https://doi.org/10.1089/jwh.2020.8472

${ }^{3}$ UN Women Asia and Pasific, "The Impact of Covid-19 on Women," (Briefs; Policy papers., UN Women, 2020), 21, https://asiapacific.unwomen.org/en/digitallibrary/publications/2020/04/policy-brief-the-impact-of-covid-19-on-women.

${ }^{4}$ Rully P. Ramli, "Dampak Virus Corona, 1226 Hotel di Indonesia Tutup," Kompas.com, April 7, 2020, https://money.kompas.com/read/2020/04/07/120414826/dampak-virus-corona1226-hotel-di-indonesia-tutup

5 Cantika Adinda Putri, "3 Bulan Corona, 3 Juta Orang Kena PHK \& Dirumahkan," CNBC Indonesia, June 3, 2020, https://www.cnbcindonesia.com/news/20200603193109-4162890/3-bulan-corona-3-juta-orang-kena-phk-dirumahkan.

${ }^{6}$ Kristianto Purnomo, "Menteri PPPA: 4.144 Pekerja Migran RI Dipulangkan, 83 Persennya Perempuan," Kompas.com, April 2020, https://nasional.kompas.com/read/2020/04/24/08271741/menteri-pppa-4144-pekeriamigran-ri-dipulangkan-83-persennya-perempuan?page=all 
unemployment for both men and women. Efforts to make a living are hampered by the PSBB (social and physical distancing) policy. The economy is paralyzed because buying interest has significantly deteriorated.

Problems arise when the economic burden shifts to women when their husbands or men experience layoffs. Many women or women end up getting odd jobs, doing anything, including folding plastic just to get a thousand two thousand rupiah, ${ }^{7}$ as well as multiple workloads at home for their domestic responsibility: managing household such as cooking, washing, in addition to the care of children. Reports indicate that the dual responsibilities carried by women potentially lead to bad health conditions such as fatigue and depression as well as make them vulnerable to conflicts or becoming domestic violence victims. ${ }^{8}$

However, the factor that contributes most to the problem is the assumption that the income must be fulfilled (sought and given by) as a man's obligation. Even during pandemic outbreak, such assumption has not changed. This is actually not only pressuring men who face difficulties in earning a living, but also women when they take the role of their husbands in earning a living during the pandemic, they are not only vulnerable to the risks as mentioned above, but also, they do not get enough appreciation. That is either in the form of rights as workers, or social appreciation. Gender norms are the cause. ${ }^{9}$

This paper will examine the concept of fulfilling a living that is more inclined to the spirit of equality and inseparability. The hypothesis of this paper is that living is a shared responsibility between husband and wife, in which both can participate,

\footnotetext{
7 Sonya Hellen Sinombor, "Terimbas Covid-19, Perempuan Pekerja Informal Mulai Menjerit," Kompas, Maret 28, 2020, https://kompas.id/baca/humaniora/dikbud/2020/03/28/terimbascovid-19-perempuan-pekerja-informal-mulai-menjerit/

${ }^{8}$ Agung Dwi Laksono, et al, "The Gender Disparities in the Psychosocial Burden of COVID-19 in East Java Province, Indonesia" International Journal of Innovation, Creativity and Change 14, no. 2, (June 2020): 498-514, https://www.ijicc.net/images/Vol 14/Iss 2/14234 Wulandari 2020 E R.pdf.

9 United Nations Population Fund, "Covid-19: A Gender Lens, Protecting Sexual and Reproductive Health abd Rights, and Promoting Gender Equality," (Technical Brief., UNFPA, 2020), 5-6, https://www.unfpa.org/sites/default/files/resource-pdf/COVID19 A Gender Lens Guidance Note.pdf.
} 
especially during a pandemic. This paper will also portray the reality in which women are actually no less capable than men to show resilience in fighting during difficult pandemic situations, whether that role is taken because their husbands are not working, or because of other factors. The data is obtained from recent studies and the results of field observations, namely the experiences of women who struggle to survive in Lamongan (East Java) and Sawangan (Depok). This paper contributes in two ways. First, to deconstruct the meaning of living. Second, to document the empirical reality of women experiences who are able to fight against difficult pandemic situations.

\section{Earnings and the Dynamics of Discriminative Terminology}

More and more Muslim women have received education and are increasingly aware of their right to work in public spaces, or at least, help men to earn a living, but Islamic orthodoxy seems to hold back by persisting to uphold patriarchal-oriented Islamic law that constructs a narrow space for women's roles. ${ }^{10}$ The definition of living income is not free from this. Wahbah al-Zuhaili explained that nafkah or maintenance means "something that a man expends for his dependents."11 The definition of Wahbah alZuhaili supposes that livelihood relates to the responsible and the dependent parties - a strict hierarchical structure. Yusuf al-Qardāwī agrees that although there is no detailed rule concerning the exact amount of maintenance that must be given, but a sufficient amount is an obligation that must be fulfilled by the husband to his wife. ${ }^{12}$ His definition further clarifies the subtexts of such hierarchical responsibility. The opinion of Wahbah al-Zuhailī and Yusuf al-Qarḍāwī slightly differ with that of Murtadha Muthahhari, which look at the history of women in Islam with a more dynamic: according to him, many female Muslims are known to actively work and receive wages. ${ }^{13} \mathrm{His}$ opinion is fundamentally different from that of Wahbah al-Zuhaili and Yusuf al-Qarḍāwī, because Murtadha Muthahhari focuses on women`s

\footnotetext{
${ }^{10}$ Gordon Means, "Women's Rights and Public Policy in Islam: Report of a Conference," Asia Survey 27, no. 3, (March 1987): 343, https://doi.org/10.2307/2644808

${ }^{11}$ Wahbah al-Zuhailī, Al-Fiqh al-Islāmī wa Adillatuhu, juz 10 (Suriah: Dār al-Fikr, 2002), 7348.

${ }^{12}$ Yūsuf al-Qarḍhāwī, Min Hadyil Islāmī Fatāwā Mu'āṣirah (Beirut: Dārul Ma'rifah, 1987), 539.

${ }^{13}$ Murtadha Muthahhari, The Rights of Women In Islam (Teheran: World Organization for Islamic Service, 1998), 213-214.
} 
independence even in marriage, based on the principles of equality between men and women.

The factor that influences the dismissal of just consideration suggested by Murtadha Muthahhari is the gender construct by language. The construct of gender language bias is achieved through standardizing definition. In Arabic, gender bias is more obvious: Arabic differentiates the use of language for men and women, yet, at different times, shows that the mention of men can represent the use of women; which indicates the presence of men is more important than that of women. ${ }^{14}$ In the Great Indonesian Dictionary (KBBI), gender construction can be seen in the definition of nafkah which includes the following: living expenses; income (money); the husband's obligation to provide his wife with provisions for daily living; means to meet inner needs; the alimony a man gives to his ex-wife based on a court ruling that finalizes the divorce. ${ }^{15}$ Two among these definitions show how the living is constructed by the dictionary as the responsibility of the husband alone. Even so in the Arabic dictionary, which refers to the definition in fiqh, living is defined as the responsibility of the husband to the wife, not described as a role that can be done with the principle of mutuality.

In addition to the dictionary, a legal product or a state policy also affects the paradigm of living as non-reciprocity. In Indonesia, the legal product that classifies a living as solely an obligation of the husband is contained in Law Number 1 of 1974 concerning Marriage (UUP), article 34 clause (1), which states that the husband is obliged to protect his wife and provide all the necessities of household life according to his ability. The same narrative is found in Presidential Instruction No. 1 of 1991 concerning Dissemination of Islamic Law Compilation (KHI), Article 80 clause (2) and (4). Depending on income, it is the responsibility of husband to provide a living, kiswah and a place to live for the wife; pay household, care and medical expenses for wife and children; as well as expend education costs for children.

${ }^{14}$ Nasr Hamīd Abu Zayd, Al-Mar'ah fi Khitāb al-Azmah (Kairo: The Legal Research and Resource center for Human Right, 1995).

15 "Kamus Besar Bahasa Indonesia: Kamus Versi Online," Badan Pengembangan dan Pembinaan Bahasa, accessed September 8, 2020, https://kbbi.web.id/nafkah. 
Lingual construction is not the sole factor playing. Political and social constructs also play a role. In the context of political construction, for example, the New Order demonstrated its persistence to reduce the emergence of female activists. Through the PKK national program and women organization Dharma Wanita (Women's Duty), the New Order construed women as "family managers", as wives and mothers who were better off just staying at home. In other words, the husband is placed as the highest hierarchy. ${ }^{16}$ Meanwhile, in social construction, religious institutions play an important role. MUI Fatwa no.7/2000 states that women cannot go abroad as Migrant Workers if they are not accompanied by their husbands, because it is stated in the preamble that their departure allows women to engage in association with men who are not mahram (family), expose their aurat (body), and endanger their safety. ${ }^{17}$ In line with this fatwa, traditional Islamic leaders also help to construct women as mothers and wives, not breadwinners. Such view is strongly justified by reference to Hadith (the traditions of the Prophet) and figh (Islamic law), including speeches made by Islamic scholars. This is especially significant in countryside areas. ${ }^{18}$

\section{Reconstructing the Terminology of Earnings}

Quranic verses which are generally referred to justify the principle of nonmutuality in living is QS. An-Nisā` 34 and QS. al-Baqarah 233.

Men are in charge of women by [right of] what Allah has given one over the other and what they spend [for maintenance] from their wealth. So righteous women are devoutly obedient, guarding in [the husband's] absence what Allah would have them guard. But those [wives] from whom

\footnotetext{
${ }^{16}$ Linda Rae Bennett, "Infertility, Womanhood and Motherhood in Contemporary Indonesia: Understanding Gender Discrimination in the Realm of Biomedical Fertility Care," Journal of Intersections: Gender and Sexuality in Asia and the Pacific 1, no.28, (September 2012): 1-12, https://reproductive-health-journal.biomedcentral.com/articles/10.1186/1742-4755-9-24

17 "Pengiriman Tenaga Kerja Wanita (TKW) Ke Luar Negeri," Komisi Informasi dan Komunikasi MUI, accessed September 8, 2020, http://mui.or.id/wp-content/uploads/files/fatwa/27.Pengiriman-Tenaga-Kerja-Wanita-TKW-Ke-Luar-Negeri.pdf

${ }_{18}$ Minako Sakai and Amelia Fauzia, "Performing Muslim Womanhood: Muslim Business Women Moderating Islamic Practices in Contemporary Indonesia," Journal of Islam and Christian-Muslim Relations 27, no. 3, (Februari 2016): 236-237, https://doi.org/10.1080/09596410.2015.1114243
} 
you fear arrogance - [first] advise them; [then if they persist], forsake them in bed; and [finally], strike them. But if they obey you [once more], seek no means against them. Indeed, Allah is ever Exalted and Grand (An-Nisa: 34). ${ }^{19}$

Mothers may breastfeed their children two complete years for whoever wishes to complete the nursing [period]. Upon the father is the mothers' provision and their clothing according to what is acceptable. No person is charged with more than his capacity. No mother should be harmed through her child, and no father through his child. And upon the [father's] heir is [a duty] like that [of the father]. And if they both desire weaning through mutual consent from both and consultation, there is no blame upon either of them. And if you wish to have your children nursed by a substitute, there is no blame upon you as long as you give payment according to what is acceptable. And fear Allah and know that Allah is Seeing of what you do (Surat al-Baqarah: 233). ${ }^{20}$

The toughest challenge is to deconstruct the paradigm of non-mutuality in providing a living as a way to challenge the narrative of religious scholars and preachers as previously mentioned. There is an increasing need to reinterpret Qur'anic verses by shifting from literal translation to a more contextual approach. This is because economic development has posed increasingly hard challenges that women must also work in the public sphere. However, the context must be based on universal-principal verses rather than particular-practical verses. ${ }^{21}$

The Qur'anic verses which endorse equality between men and women, including in terms of earning a living, are far more varied than the two verses often quoted by the preachers. Verses regarding that matter can be found in QS. Hūd: 61, which states that mankind is originally created from the earth (soil) and Allah asks humans to

19 "Qur'an Kemenag," LPMQ Kemenag, accessed September 11, 2020, https://quran.kemenag.go.id/sura/4

20 "Qur'an Kemenag," LPMQ Kemenag, accessed September 11, 2020, https://quran.kemenag.go.id/sura/2

${ }^{21}$ Ahmad Al-Raysūnī, Imām al-Shātibī's Higher Objectives and Intents of Islamic Law (London: The International Institute of Islamic Thought, 2005),112. 
prosper the earth in a great purpose to worship Allah. This indicates that the responsibility to prosper the earth is entitled to all humans without exception. The next verse can be found in QS. Al-Jum 'ah: 9-10, which states that believers must leave economic matters when the time for Friday prayer arrives and only then are believers advised to scatter on earth to reap Allah's blessings. This order is addressed to believers, not only men. The next verse, QS. Āli Imrān: 195, which states that God has assured to equally reward the deeds of both men and women who work for a living. Lastly, the order to share the burden of living can be found in QS. al-Kahfi: 110, which states that those who will encounter Allah in heaven are both men and women who sincerely work in a good way and do not associate Allah with others.

There is also a group of verses which narrates the history of women who are rightfully appreciated for their public works. Queen Bilqis (narrated in QS. Al-Naml: 20-24), is a female political and economic leader of Saba who has successfully brought prosperity to her people. Another verse tells the story of two daughters of the Prophet Syu'aib (in QS. al-Qașaș: 23-28) who actively work as breeders and hold responsibility for their family welfare as well as show great bravery by following men to get water from public wells. These verses are supported by a verse which states that men and women should not be jealous of each other's gains, because Allah has distributed them fairly (in QS. al-Nisā': 32).

A sahih hadith states that the Prophet prohibits husbands from preventing their wives when asked permission to work. ${ }^{22}$ Thus, Islamic history has recorded the existence of many women who independently ran businesses and jobs which demanded quite high mobility. Zainab binti Jahsy was known as a skilled craftsman who not only produced but also sold her products independently. ${ }^{23}$ Qilat Ummi Banī Ammār was a woman who was recorded visiting the Prophet to specifically ask for advices in commerce, regarding how to decide the price of her products justly. ${ }^{24}$ The aunt of Jarir bin Abdullāh was reprimanded by someone because she wanted to go to work during her

${ }^{22}$ Abu Abdullāh Muhammad bin Ismāil al-Bukhari, Al-Șahīh al-Bukhārī, vol. 1 (Beirut: Dār alFikr, tanpa tahun), 220.

${ }^{23}$ Abu Husein Muslim bi Al-Hajjāj bin Muslim, Al-Șahīh al-Muslim, vol. 7 (Riyādh: Dār al-Salām, tanpa tahun), 144.

${ }^{24}$ M. Quraish Shihab, Membumikan al-Qur'an: Fungsi dan Peran Wahyu dalam Kehidupan Masyarakat (Bandung: Mizan, 1996), 275. 
'iddah period. She complained to the Prophet and instead allowed to do so as long as having good intention. ${ }^{25}$ As for Rițah binti Abdullāh, the wife of Ibn Mas 'üd, was indirectly permitted to work by the Prophet to support her husband and children. ${ }^{26}$

The universally principled verses hadiths above indicate that Q S. An-Nisā': 34 and QS. al-Baqarah: 233 is more of a conditional choice for both husbands and wives than commands regarding halal-haram. Sayyid Quțb interprets QS. an-Nisā’: 34 as a nonstandard distribution of household organization and is more of an expression of the husband's affection who avoids distributing his burden to his wife. ${ }^{27}$ Hence, other conditions can arise and change the distribution of the organization. Then QS. anNisā': 34 should be interpreted in a transformative and humanistic spirit. The word al-rijāl in the verse actually means husband, which therefore limits the context of the discussion (it is no longer a verse about the hierarchy of men and women, but about the general responsibility of a man for a woman). ${ }^{28}$ Whereas qawwāmūn in the verse means a constant guardian, who is responsible for guiding a family (ahl al-qiyām). ${ }^{29}$ Artinya, statemen yang diberikan al-Qur'an jauh dari maksud doktrin kekuasaan lelaki. This means that the statement given by the Quran is not about the doctrine of male power per se. The verse merely expresses the principles of equality and a fair role between men and women.

The transformative and humanistic interpretation above is more contextual; the old doctrine of non-mutuality in providing a living can no longer serve as a way out of the economic difficulties arisen in this increasingly industrialized world, especially in times of pandemics.

\footnotetext{
${ }^{25}$ Abu Husein Muslim bi Al-Hajjāj bin Muslim, Al-Ṣahīh al-Muslim, vol. 4 (Riyādh: Dār al-Salām, tanpa tahun), 200.

${ }^{26}$ Abu Abdullāh Muhammad bin Ismāil al-Bukhari, Al-Șahīh al-Bukhārī, vol. 4 (Beirut: Dār alFikr, tanpa tahun), 68

${ }^{27}$ Sayyid Quțb, Tafsīr Fī Z̦ilalil Qur'ān: di Bawah Naungan Al-Qur'an, jilid 22, trans. As'ad Yasin (Jakarta: Gema Insani Press, 2004), 175

${ }^{28}$ Abdurrahman, dkk., Al-Qur'an dan Isu-isu Kontemporer (Yogyakarta: eLSAQ Press, 2011), 341.

${ }^{29}$ Muhammad bin Jarīr at-Ṭabarī, Tafsìr al-Tabarī Jāmi' al-Bayān 'an Ta'wīl Āyāt al-Qur'ān (Kairo: Maktabah Ibnu Taimiyyah, tanpa tahun), 290.
} 


\section{The Reality at the Grassroots}

The problem of non-mutuality in providing a living as previously described, ultimately needs to be checked and reviewed with the reality at the grassroots. This research gives conducts interviews with several women in Sendangagung.

Sendangagung is carefully chosen because of its Muslim society`s unique character. Historical investigation of local leaders shows that Sendangagung is a rest area for wali during transition era from Majapahit to Demak Islamic. Thus, the people of Sendangagung are also known as religious people. Religious devotion shown by devoted acts of worship in mosques and charity, especially on certain days (Friday or religious celebration day). The influence of Sendangagung as the rest area of wali is still well preserved. In Sendangagung, there are several pesantrens (Islamic boarding school). Among them are Pesantren al-Ishlah in Sendangagung, Pesantren Raudlatut Thalabah in Sendangduwur, and Pesantren Al-Muhtadi in Sendangagung. ${ }^{30}$ This particularly religious character is an important consideration to measure whether Muslim women are allowed to work in Sendangagung. Because until 2000s, Sendangagung people were also well known as entrepreneurs and craftsmen. Sendagnagung is an area with highly active economic activity. ${ }^{31}$ Only in the early 2000 s, there was an invasion of investors and packaging craftsmen using machine technology, while at the time, the people of Sendangagung were still consistently making handmade products. In terms of production speed and the ability to fulfill orders, Sendangagung's investors and craftsmen fell behind. There were very little people who continued the business. While the rest of the community turned to tailoring business. Additionally, those who were unemployed would leave the area. Those who shifted to other jobs did not much succeed, nor did those who left. So, after the 2000s, the economy of Sendangagung people experienced a drastic decline. Those who shifted and unsuccessful were mostly people doing odd jobs like selling dawet ental (lontar fruit) or selling typical plants of Sendangagung. The development of Al-Ishlah Sendangagung Islamic Boarding School which was founded by Al-Ustadz Muhammad Dawam Saleh in 1986 had helped make economic condition better. The

\footnotetext{
${ }^{30}$ H. Milkan, interview, June 4, 2020.

${ }^{31} \mathrm{H}$. Milkan, interview, June 4, 2020.
} 
economy has recently revived, with culinary and broidery businesses. During the pandemic, the economic situation is weakened for the second time. ${ }^{32}$

In such context, women work hand in hand with men trying to keep the economy running, at least to fulfill their daily needs. This research will examine two women from two different families, namely Roro Iswati and Mbok Sih. Roro is a young woman who lives with her husband and two children, as well as her entire extended family (mother, brother, sister, and aunt). Mbok Sih is a widow with one child, who is recruited by pesantren Al-Ishlah Sendangagung to sell beverage. They attempt to prove that; women are no less capable than men to make ends meet.

\section{Roro Iswati ${ }^{33}$}

This 35-year-old woman is a native of Sendangagung. Due to lack of funds, her education ended at Junior High School (SMP). She attended SMP Muhammadiyah (SMPM-12) Sendangagung. Since her childhood, when she was a fourth grader at Madrasah Ibtidaiyah Muhammadiyah (MIM-13), she had worked for her poor family. She said that she had worked as a shopkeeper which salary she saved to pay for her own education. This condition lasted until she was in junior high school when she stopped her own dream to continue her education. She was insecure, disappointed and angry with the situation, endlessly crying and locking herself up in her room where she expressed her disappointment and anger at her crushed dream to go to school.

Not wanting to wallow in self-pity and sadness and believing that life must go on, she tried to survive by doing whatever job she could find. While working as a laundrywoman, stationary store clerk, picking up and dropping children off at school, she had to relive school memories that she had to imagine continuing her education. Every time she passed the gates of the school and pesantren, Roro Iswati admitted that she was always determined and prayed hopefully, that her children would be able to pursue education to highest level. Therefore, her children do not experience the same fate as her. When asked whom she spent these days working hard and survived for, Roro replied that her main wish was to pay for his children to go to school

\footnotetext{
${ }^{32}$ H. Milkan, interview, June 4, 2020.

${ }^{33}$ Roro Iswati, interview, June 4, 2020.
} 
to achieve their dreams. "I do not want my children to go through the same fate as me, having no funds to continue education to a higher level." However, Roro's burden is not only the children. As the second of three children, Roro and her husband also provide for the daily needs of her extended family who lives in the same house as her (mother, sister, brother, aunt, and two children). Her husband (41 years), who married her in 2005, is a construction worker at the junior high school where she went to school.

It is said that Roro Iswati was known to be quite intelligent when she was in school. She was known for her creativity and determination. Even though she is only a junior high school graduate, she is not reluctant to do whatever is important to get a halal income. Her creativity and optimism in carrying out her life are the pillars that support her family`s economy. Especially when the corona outbreak hit all regions of the world, including Sendangagung. Economic activity stagnates. There are no more street vendors. There are no more crowds. Most people choose to stay at home. They prefer to cook by themselves. Almost no one buys food from outside.

In such pandemic situation, many workers including Roro's husband, who works as a construction worker at junior high school, temporarily must stop for a while. Considering that everyone is required to rest at home and avoid crowd as well as carry out health protocol and corona prevention, inevitably, Roro must step up as the sole source of the family's economy. She has four additional main jobs, especially during corona outbreak. They include online vegetable delivery service; ecommerce selling household items, stationery/ books, shoes, masks, and so forth; domestic worker especially to iron clothes; and mosque cleaning staff to keep the mosque clean every morning.

As an online vegetable service delivery, she uses her Android phone to communicate with customers. Since night until dawn, Roro carefully collects the data of customer orders. At around 6:00 am, with complete standard attributes for virus prevention (mask, jacket, plastic face covers, hand sanitizers, rubber gloves, etc.) she goes to the market to buy the orders of the customers. From this business, she takes profit from the gap of the price, as well as shipping costs calculated per transaction which she charges Rp. 6 000, -. 
The net gain of online vegetable delivery service quite helps her survive and support her family as well as spare savings for her children`s education. During pandemic, it is safe enough for the ever-tenacious Roro to say that she secretly feels blessed. There is an increasing order for her online vegetable delivery service. In fact, she has to add her purchasing time not limited to the morning in Gayam market (which opens at 05:30 until 07:00), but also in Sendang market (which opens at 07.30 until 10:00). Moreover, in Ramadhan, household wives typically place orders since noon. The pandemic gives her opportunity to survive and save more from her online vegetable delivery service. Nevertheless, she must risk herself going to crowds-which makes her vulnerable to the Covid-19 virus.

Usually she finishes purchasing the orders at 9:30 a.m. After that, usually Roro will take a short break, while also prepares herself to go to the blue mosque in Sendangagung village. After Zuhr, she is to sweep, mope and clean every little crook in this beautiful two-story mosque. Roro is known for her work speed. Together with her colleague, she cleans the mosque only within an hour and finishes at 13:00. She performs cleaning job every day, except on Friday, she and her colleague clean up the mosque early as a preparation for the Friday prayers. Meanwhile, she does not become domestic worker for ironing clothes every day, but only three days a week.

From cleaning the mosque and ironing clothes, she gets extra money for her children's education savings. For Roro, these two jobs are only side jobs for additional savings. Her main jobs are online vegetable delivery service and ecommerce. The latter is done by making WhatsApp's status consisting of product photos, descriptions and promotions. She seems happy when asked of her income from both jobs. She will only answer while blush: "Alhamdulillah, enough."

The online products she sells are purchased directly from small entrepreneurs specialized in shoes, masks, school bags, stationery, and others. She makes profit from the difference in the price as well as a bonus from the owner of the goods if she successfully sells in a certain amount. Her principle of the work is service and trust. If people need her to help sell their products, she gladly accommodates them. Similarly, if people need any item, she will try to meet their needs.

She performs jobs that require high mobility (which demanded her to leave the house as often as possible, with the risk of pandemic exposure). With great dedication, Roro 
is capable to do well. Her only principle is to support her family as well as pay the cost of her children's education for their bright future. She faces two forms of verbal abuses: because she is a woman who is the backbone of the family and her jobs are not deemed prestigious. She said: "Let people laugh and insult my jobs, all that is important is that I do not beg for money, and I work in a lawful way." This is a form of endeavor which she calls a way to always depend on Allah SWT, the Most Rich. "I always pray that I wish my children the success of both life and afterlife. Aamiin." She concludes.

\section{Mbok Sih ${ }^{34}$}

Mbok Sih comes from Pucuk, Lamongan and lives in Sendangagung for the past 5 years. She moved to try her luck. She is a widow with two children. Her first child lives with her brother in Pucuk, while studying at a boarding school. Meanwhile, her second child lives with her in Sendangagung. After divorce from her husband, she is a single parent to her two children. Moving is an option to find decent work to support her two children.

Since her arrival in Sendangagung, Mbok Sih has applied for work at Pondok al-Ishlah Sendangagung. To complement her income beside her job at pesantren, she sells beverages for the students. The income as a pesantren employee and helping to make ice candles is enough to pay for her two children to go to school, as well as daily expenses, and to save money. Regarding accommodation and the cost of food, Mbok Sih feels more eased. Because as a pesantren employee, Mbok Sih lives in the employee dormitory, and for daily meals, Mbok Sih eats in the santri kitchen which is also provided for employees and teachers who live in pesantren. This applies in normal times when the students are studying and living in the cottage. When the students are on vacation, Mbok Sih returns to Pucuk.

During the pandemic, Mbok Sih's normal life cycle changes. The life of santri in pesantren is one of the main sources of her economic life. During school breaks, in terms of income, Mbok Sih only relies on the salary from the boarding school. There's no extra income from selling beverage. However, during the pandemic, all educational institutions in all districts in East Java are to implement health protocols. Among those

${ }^{34}$ Mbok Sih, interview, June 4, 2020. 
who are expected to be watchful are members of the boarding school. In fact, pesantren already has regulation which prohibits visits; all students, teachers and employees are not allowed to leave the boarding school from the start; which is enough to prevent virus expansion. However, the district's Education Agency and Ministry of Religious Affairs compels a cautionary policy. Following the Central Government, they dismiss students and end their school activities faster. Pondok alIshlah's holiday is accelerated from May 13-14, 2020 to April 14-15, 2020.

Since then all Mbok Sih's economic activities have also stopped. She only relies on a monthly salary from the boarding school. Amid this hard time, Mbok Sih courageously shares her situation to Bu Nyai of al-Ishlah boarding school. Fortunately, she responds well and helps Mbok Sih by giving her extra work during school break, mainly to help in the kitchen and iron clothes.

When asked what she feel when she bravely reports her situation to Nyai, she replies: seng penting aku kudu wani matur ke bu Nyai. Seng tak pekerno iku yo mung anakku dan kebutuhanku sekeluarga. Aku nggak nggellem bergantung ke belas kasihan orang. Aku nduwe tenaga seng iso dimanfaatkan untuk memperoleh penghasilan tambahan, yo aku matur, Kak, yang penting dan saya rasakan saya harus berani menyampaikan ke bu Nyai. She feels the urgency to tell Nyai because she only thinks of her children and her family's needs. She also hates relying on people's pity while she has strength to earn extra income, so she boldly conveys it to Nyai.

\section{Nur Wati ${ }^{35}$}

Apart from Roro Iswati and Mbok Sih, there is also Mpok Nur Wati, 53 years old woman from Bojong Sari, Sawangan, Depok. Living in the border area of Depok and South Tangerang, which is only $20 \mathrm{~km}$ away from the state palace, does not make it easy for her to get access to aid during pandemic. The area where Mpok Nur lives is in the red zone for corona virus outbreak. Consequently, since the end of March to June, Mpok Nur`s economic activity is highly restricted. Mpok Nur cannot get into the housing complex to sell her goods as she is a vegetable seller. On a daily basis, usually from dawn to evening, Mpok Nur can go around three residential complexes to sell vegetables.

\footnotetext{
${ }^{35}$ Nur Wati, interview, June 4, 2020.
} 
The limited entry of outsiders to the housing complex is carried out by the management of the local complex to anticipate the spread of the virus. This situation is not easy for Mpok Nur. To get around this situation, Mpok Nur shares her WhatsApp number to the complex residents. Mpok Nur receive orders through that. She collects a data of which vegetables each customer wants to buy. Then, Mpok Nur will deliver orders in three ways: give them to the complex security guard (for a complex that prohibits outsiders from entering the complex), deliver them at the front fence of the customer's house (for a complex that does not prohibit outsiders from entering), or meet with buyers outside the complex. Transactions can be made by transfer or cash.

Initially, Mpok Nur is pessimistic about the prohibited entry to the complex. Mpok Nur is also little depressed at the thought of a much-reduced income compared to what she used to receive before the pandemic. However, by shopping and ordering online, Mpok Nur finds herself more empowered. She said happily: "I find blessings in disguise from this virus for poor people like me. There are people who never buys vegetables from me, but they do. New customers even come from distant complexes such as from Pamulang Estate." Mpok Nur said that the range of orders via WA is growing fast. Usually, Mpok Nur will send photos of the vegetables or fruits she sells. If the buyer agrees to the items, they will be delivered. In addition to the increasing range of buyers, her sales are increasingly better. Mpok Nur can sell 15 chickens a day, and this is more than the days before the pandemic, when on average she could only sell seven chickens a day. Likewise, for vegetables, fruit and other goods. Orders also become more diverse.

Mpok Nur seems more concerned about her economic situation than fear of virus. She does not want to stay at home and do nothing about it. For her, washing her hands and wearing a mask is enough to avoid the virus while she is working.

\section{Conclusion}

Living is not the sole duty of men and only becomes the monopoly of the husband. It has complex and flexible dynamics: women are allowed to be involved in earning a living when circumstances demand. The situation referred to in this case is not only a partial context (demands in the household), but also a global context (demands of the times). This is because the verses of the Quran talk more about the universality of equality between men and women, including in terms of earning a living. As 
evidenced in QS. Hūd: 61 about the creation of mankind (male and female) from the ground to worship Allah. Also, message found in the QS. Al-Jum'ah: 9-10 regarding the obligations of believers (men and women) to leave economy when Friday prayers time comes and after that they can scatter on the face of the earth looking for rizki. In QS. Āli Imrān: 195, men and women who work for a living would not be wasted by God but rewarded. Other clues are found in a collection of historical verses, some of which tell the stories of women who were rewarded for their work in the public space, such as Queen Bilqis in QS. al-Naml: 20-24, two daughters of Prophet Syu'aib in QS. alQașas: 23-28.

There are also many indications in hadith that lead us to the conclusion that women are allowed to earn a living. First, the Prophet prohibits husbands from preventing their wives from asking permission to work. Second, the example of Zainab bint Jahsy, who was a reliable craftswoman who independently produced and sold her products. Prophet discussed with Qilat Ummi Bani Ammār on setting fair price for her goods. Prophet also allowed aunt of Jarīr bin Abdullāh to work during 'iddah period as long as it was in the spirit of goodness. Rițah bint Abdullāh, the wife of Ibn Mas'ūd, was even permitted by the Prophet to support her husband and children. The list mentioned above shows that the obligation to provide a living can extend to women not only because the text allows it, but because, women have the same ability as men to work for a living. The old doctrine of non-mutuality in providing a living can no longer offer solution to current economic difficulties that have arisen in this increasingly industrialized world, especially in times of pandemics. The demands of the times require that many women participate in earning a living, and their efforts should not be discredited. 


\section{Bibliography}

Abdurrahman, e. a. (2011). Al-Qur'an dan Isu-isu Kontemporer. Yogyakarta: eLSAQ Press.

Abu Zayd, N. H. (1995). Al-Mar'ah fi Khitāb al-Azmah. Kairo: The Legal Research and Resource center for Human Right,.

al-Qarḍhāwī, Y. (1987). Min Hadyil Islāmī Fatāwā Mu'āṣirah. Beirut: Dārul Ma'rifah.

Al-Raysūnī, A. (2005). Imām al-Shātibī's Higher Objectives and Intents of Islamic Law. The International Institute of Islamic Thought, 112.

al-Zuhailī, W. (2002). Al-Fiqh al-Islāmī wa Adillatuhu (Vol. 10). Suriah: Dār al-Fikr.

Badan Pengembangan dan Pembinaan Bahasa. (2020, September 8). Kamus Besar Bahasa Indonesia: Kamus Versi Online. Retrieved September 8, 2020, from kbbi.web.id: https://kbbi.web.id/nafkah.

Bennett, L. R. (2012, September). Infertility, Womanhood and Motherhood in Contemporary Indonesia: Understanding Gender Discrimination in the Realm of Biomedical Fertility Care. Journal of Intersections: Gender and Sexuality in Asia and the Pacific, 1(28), 1-12. Retrieved from https://reproductive-healthjournal.biomedcentral.com/articles/10.1186/1742-4755-9-24

Cai , H. (2020, April). Sex difference and smoking predisposition in patients with COVID-19. The Lancet, Respiratory Medicine, 8(4), e20. doi:10.1016/S22132600(20)30117-X

Gausman , J., \& Langer, A. (2020, April). Sex and Gender Disparities in the COVID-19 Pandemic. Journal of Woman's Health , 29(4), 465. doi:https://doi.org/10.1089/jwh.2020.8472

Ismāil al-Bukhari, A. b. (n.d). Al-Șahīh al-Bukhārī (Vol. 1). Beirut: Dār al-Fikr.

Ismāil al-Bukhari, A. b. (n.d). Al-Șahīh al-Bukhārī (Vol. 4). Beirut: Dār al-Fikr.

Jarīr at-Ṭabarī, M. b. (n.d). Tafsīr al-Tabarī Jāmi' al-Bayān 'an Ta'wīl Āyāt al-Qur'ān. Kairo: Maktabah Ibnu Taimiyyah.

Komisi Informasi dan Komunikasi MUI. (2017, Februari 22). Pengiriman Tenaga Kerja Wanita (TKW) Ke Luar Negeri. Retrieved September 8, 2020, from mui.or.id: http://mui.or.id/wp-content/uploads/files/fatwa/27.-Pengiriman-Tenaga-KerjaWanita-TKW-Ke-Luar-Negeri.pdf 
LPMQ Kemenag. (2020, September 11). Qur'an Kemenag. Retrieved September 11, 2020, from quran.kemenag.go.id: https://quran.kemenag.go.id/sura/4

LPMQ Kemenag. (2020, September 11). Qur'an Kemenag. Retrieved September 11, 2020, from quran.kemenag.go.id: https://quran.kemenag.go.id/sura/2

Means, G. (1987). Women's Rights and Public Policy in Islam: Report of a Conference. Asia Survey, 27(3), 343. doi: https://doi.org/10.2307/2644808

Milkan , H., Sih , Wati , N., \& Iswati , R. (2020, Juni 4). Bagaimana perempuan di Sendangagung mencari nafkah semasa pandemi? (Y. Muthmainnah, \& R. Z. Khaidir, Interviewers)

Muslim, A. A.-H. (n.d). Al-Șahīh al-Muslim (Vol. 7). Riyādh: Dār al-Salām.

Muslim, A. A.-H. (n.d). Al-Șahīh al-Muslim (Vol. 4). Riyādh: Dār al-Salām.

Muthahhari, M. (1998). The Rights of Women In Islam. Teheran: World Organization for Islamic Service.

Purnomo, K. (2020, April 24). Menteri PPPA: 4.144 Pekerja Migran RI Dipulangkan, 83 Persennya Perempuan. Jakarta, DKI Jakarta, Indonesia. Retrieved April 24, 2020, from https://nasional.kompas.com/read/2020/04/24/08271741/menteri-pppa-4144-

pekerja-migran-ri-dipulangkan-83-persennya-perempuan?page=all

Putri, C. A. (2020, Juni 3). 3 Bulan Corona, 3 Juta Orang Kena PHK \& Dirumahkan. Jakarta, DKI Jakarta, Indonesia. Retrieved from https://www.cnbcindonesia.com/news/20200603193109-4-162890/3-bulan-corona3-juta-orang-kena-phk-dirumahkan

Quțb, S. (2004). Tafsīr Fi Zilalil Qur'ān: di Bawah Naungan Al-Qur'an (Vol. 22). (A. Yasin, Trans.) Jakarta: Gema Insani Press.

Ramli, R. P. (2020, April 7). Dampak Virus Corona, 1226 Hotel di Indonesia Tutup. Jakarta, DKI Jakarta, Indonesia. Retrieved April 7, 2020, from https://money.kompas.com/read/2020/04/07/120414826/dampak-virus-corona1226-hotel-di-indonesia-tutup

Sakai, M., \& Fauzia, A. (2016, Februari). Performing Muslim Womanhood: Muslim Business Women Moderating Islamic Practices in Contemporary Indonesia. Journal of Islam and Christian-Muslim Relations, 27(3), 236-237. doi:10.1080/09596410.2015.1114243 
Shihab, M. Q. (1996). Membumikan al-Qur'an: Fungsi dan Peran Wahyu dalam Kehidupan Masyarakat. Bandung: Mizan.

Sinombor, S. H. (2020, Maret 28). Terimbas Covid-19, Perempuan Pekerja Informal Mulai Menjerit. Jakarta, DKI Jakarta, Indonesia. Retrieved Maret 28, 2020, from https://kompas.id/baca/humaniora/dikbud/2020/03/28/terimbas-covid-19perempuan-pekerja-informal-mulai-menjerit/

UN Women Asia and Pasific. (2020). The Impact of Covid-19 on Women. New York: UN Women. Retrieved from https://asiapacific.unwomen.org/en/digitallibrary/publications/2020/04/policy-brief-the-impact-of-covid-19-on-women.

United Nations Population Fund. (2020). Covid-19: A Gender Lens, Protecting Sexual and Reproductive Health abd Rights, and Promoting Gender Equality. New York: UNFPA. Retrieved from https://www.unfpa.org/sites/default/files/resourcepdf/COVID-19_A_Gender_Lens_Guidance_Note.pdf.

Wulandari , R. D., Putri, N. K., \& Laksono , A. D. (2020). The Gender Disparities in the Psychosocial Burden of COVID-19 in East Java Province, Indonesia. International Journal of Innovation, Creativity and Change, 498-514. Retrieved from https://www.ijicc.net/images/Vol_14/Iss_2/14234_Wulandari_2020_E_R.pdf. 